DOI: 10.2478/RAE-2019-0028 Review of Artistic Education no. 182019 255-261

\title{
6. THE BEGINNINGS OF THE MODERN ART
}

\section{Mircea Ştefănescu ${ }^{270}$}

\begin{abstract}
At the beginning of the 20th century visual artists found in the art the perfect field to experiment with different materials, combinations of new shapes and proportions to create new artistic currents. But this new trend has questioned the relation of classical arts with its perennial values which can not be overlooked, however radical the desire of young artists to "break" definitively with the past. Thus, in this new artistic context, many of the old art flagship techniques have been questioned and, as is always the case for predicting the "future of art", the new artistic tendencies are absolutized and others are considered obsolete and declared "death". The best known example is that of Marcel Duchamp, who, along with his famous ready-made exhibitions, strongly supported the death of art. Finally, the great creators of the past century felt at one point the need to relate to established art in order to better understand the "place" occupied by the generation of new artistic revolutions.
\end{abstract}

Keys words: the modern art, ready-made, artistic revolutions, experiment, tendencies

\section{Introduction}

The Contemporary plastic art has become a phenomenon intertwined with other forms of visual expression, including technical subjects, on the one hand, thanks to artists who have sought new means of transmitting and storing the artistic message, and, on the other hand, thanks to the desire of the people in other fields to express themselves artistically. This melange, based on the spread of technology to the masses, puts into question even the classical definition of the contemporary visual artist. From the excess of zeal by newcomers on the visual arts territory, they have arrogated the status as creators, reducing the classical artist's definition to the level and status of a craftsman.

Although it is a healthy attitude, experiencing the new technologies and attempting to associate with the aesthetic valences attributed not so long ago to traditional $\operatorname{arts}^{271}$, the absolutisation of the computer, at few decades after its appearance in the way of life of certain categories of people when the time has not yet exhausted his word, it's a taken risk too easily. Let's not forget that the grave consequence of the lifestyle dedicated to consumerism is the immense amount of waste, which can be also of artistic nature. The serial production reduces the value of any product. The desire to achieve the art with technique, allowing the multiplication without the possibility to control of product, leads to

\footnotetext{
270 Lecturer PhD., "George Enescu" National Universitz of Arts from Iași, Romania, email: mirceastefanescu@yahoo.com

${ }^{271}$ See Mirela Ștefănescu Arta vizuală ieșeană intre tradiție și inovație, Review of artistic education, nr. 1314/2017, Ed. Artes, Iași, 2017, p. 221
} 
the appearance of saturation phenomenon. Contrary to commercial laws, a true work of art will never become an object to sell second hand. Reducing the artist's contribution only to the concept behind a product, whether artistic and its lack of direct involvement in the realization of the object rather than as a simple space decorator, increases the degree of artificiality in the artistic creation.

\section{Discussions}

The idea that "art dies" launched by Hegel who sees the art history enrolled in a wider evolution of the spirit in history, and he characterizes art as an evolution of the idea of absolute, which will inevitably lead to the end. Actually, Hegel wishes to draw attention to the end of the art defined by Aristotle as an imitation of nature. This end will be in the moment when the art no longer fulfills its specific function and it will transmite the message to another spiritual, actually to philosophy, which has an infinite degree of abstraction. "The art no longer offers that satisfaction of the spiritual needs that previous times and civilizations seek in it. The art is and remains for us, in terms of its supreme destination, something that belongs to the past" ${ }^{272}$.

From the second half of the nineteenth century the visual art assimilates and incorporates different techniques from the period such as photography, cinematography or opera and theater performances, which actually led to an unprecedented change of the visual arts. In this new artistic context many of the old flagship techniques of art have been discusse and, as it is alway the case when it comes to predicting the "the future of art" the new artistic tendencies are absolutized and others are considered obsolete and declared "dead". The greatest desire was to produce sensation. A new scandal in mass-media is actually free advertising and a simple way to become overnight a person who they are talking about. The important thing is that it speaks, it doesn't matter the if it is pros and cons. Are contemporary artists so original that they have thought of this method, or has it been tested? These "deads" of the art are not a novelty, and their affirmation is rather an advertising character to draw attention to the one who makes this statement than to conclude a fulfilled fact.

The best known example is the artist Marcel Duchamp, who, along with the exposition of his famous ready-made, he strongly supported the death of the art. This moment is actually taken over by many artists who don't treat with the same importance another interview with Marcel Duchamp in which, after almost two decades after his "terrible" statement, he is asked to comment on his words from his youth. It is only this answer which deserves to remain in the history of the arts: "And God makes mastakes sometimes" 273 said Marcel Duchamp, who became famous after having exhibited a urinal called The Fountain.

\footnotetext{
272 G.W.F. Hegel, Prelegeri de Estetică, vol.1 Editura Academiei Republicii Socialiste România, București, 1966, pag. 16-17

${ }^{273}$ Matthew Collings This Is Modern Art a TV series written and presented by the art critic in 1999
} 


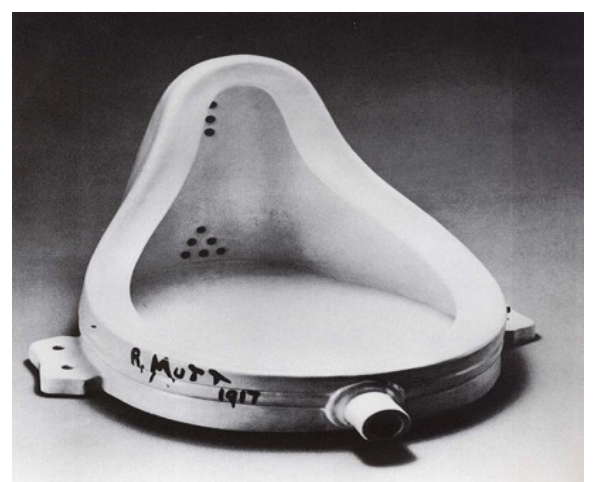

Fig. 1. Marcel Duchamp, The Fountain, 1916

His friendship with Constantin Brâncuşi changed the destiny of the sculptor for good. Each artist, in his own way, has taken decisive steps to expand the sphere of visual arts. The reason I have remembered them is that both (and they are not the only examples) have made the transition from figurative art to abstract art only after they have mastered the techniques of classical arts.

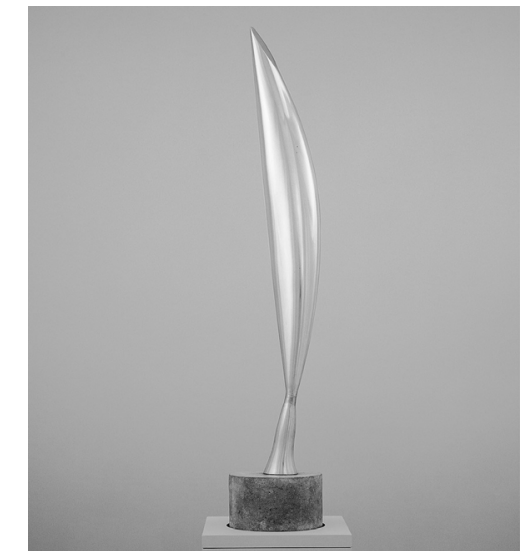

Fig. 2. Constantin Brancusi, Bird in Space, $1919^{274}$

Here it is the impression of the changes which took place in the art of the 20th century, Petru Comarnescu ${ }^{275}$, a man who lived in the artistic environment over the Atlantic Ocean and who knew very well the creative atmosphere of the last century, when the artists were looking for new currents and roads in art: "I think with indifference to the contrast between the ways in which artistic creation is conceived by two great categories of artists. One category believes that in order to be modern in art, it is necessary to deny your predecessors and break with everything that has been done to you. They dispute whatever was

\footnotetext{
${ }^{274} \mathrm{https}: / /$ www.google.com/search?q=constantin+brancusi

${ }^{275}$ Petru Comarnescu (November 23, 1905, Iasi, November 27, 1970, Bucharest) was a literary critic, essayist, memorialist, cultural journalist and known Romanian angel, one of the founders of the Criterion interwar period (1934), Mircea Vulcănescu and Alexander Christian Tell. Primary School in Iasi, High School in Iasi and Bucharest, St. Sava College, then follows the courses of the Artillery School in Craiova. He was licensed in Law in 1928 and in Letters and Philosophy in 1929. In 1931 he went to the USA where he obtained the Doctorate at the University of Southern California, Los Angeles, with the work The Nature of Beauty and Its Relation to Goodness (published in Romanian under the title Kalokagathon). It will be equaled only in 1966 with a Romanian doctorate in History of Arts.
} 
created before them. I think being modern means denying your precursors. There are painters who give up not only the inspiration from cult and popular art, but also from painting itself, as well as sculptors who are no longer carving. What are they doing in return? All sorts of trivial objects, devoid of any higher significance, of any spirituality" ${ }^{276}$.

The develope conceived by historians, the reinvigoration of creation by interfering with the relationships between artists from different generations or schools, the acquiring of new syntheses, including the guidance, influences, impulses of forerunners, combined with own contributions, overflows and jumps, attesting the originality, novelty, the strength of the new work, seem to be outdated for today's artists. Creative geniuses such as Leonardo Da Vinci, El Greco, Pablo Picasso, Constantin Brâncuși or Marcel Duchamp have had forerunners that they have overcome or accomplished. Of course, the formation of an artist is complex and can't be summed up just to the advice, direct or indirect, of a master or of a current or a school ${ }^{277}$. Brancusi, aware by the value of the styles of popular art, to whom he gave an original look, he broke the connection with academicism and Rodin's influence. The color of Russian popular art from Kandinsky's abstract paintings are based on childhood echoes and the meanings of truly lived experiences. Henry Moore is inspired by monumental menums and metamorphoses of geology. The artists did not create ignoring the history and what was done before them but they sought to perfect their artistic works through perfection or craftsmanship. "If they sometimes proved spontaneity, it was based on lengthy exercises and meditations" ${ }^{278}$. What can be more confusing for the amateur of art when he observes how in the exhibition halls, the renewal of art, or the art revolution is, actually, the lowering of exhibitor's artistic training level, just to bring a new air. The twentiethcentury artist, fascinated by technical revolutions, wants to make the switch from manufacturing to production line to serialism, but in the eyes of the art public this change is perceived as the famous photograph "Jump in the Void" by Harry Shunk.

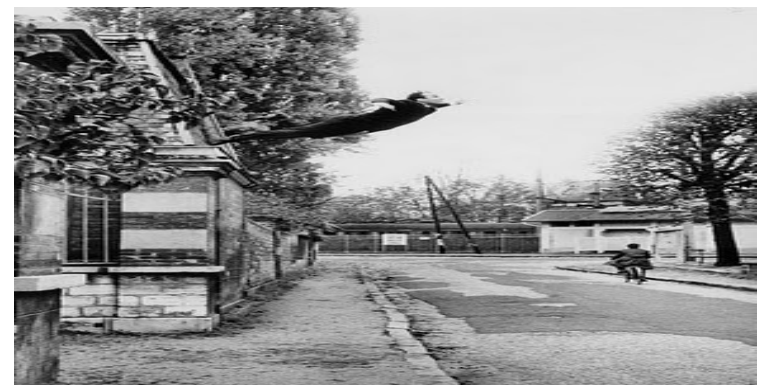

Fig. 2. "Jump in the Void" - Photo by Harry Shunk after a performance by Yves Klein held in Rue GentilBernard, Fontenay-aux-Roses, October 1960. ${ }^{279}$

\footnotetext{
${ }^{276}$ Petru Comarnescu, Confluențe ale artei universale despre Negație și negativism în plastica modernă, Ed. Meridiane, București, 1972, pag.205

${ }^{277}$ See Mircea Ștefănescu, Arta desenului. Studiul portretului și al corpului uman după model, Ed. Artes, Iași, 2015

${ }_{278}^{27}$ Petru Comarnescu Op.cit.

${ }^{279} \mathrm{http} / / /$ blog.gabrielaphotography.com/artisti/yves-klein/
} 
After almost a century of feverish searches, when we find only a few creations which have surpassed the ready-made moment of birth, it becomes obvious that, at present, the return of art to the normal course, to the artistic object, unique, endowed not only with aesthetic valences but also with the aura transferred and assumed by the artist at the moment of work, becomes an option that is self-imposed.

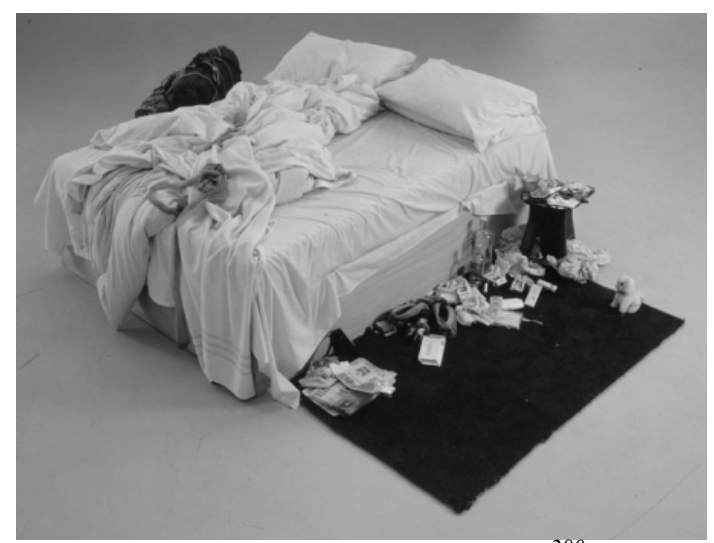

Fig. 3. Tracey Emin, My Bed, $1998^{2}$

The great creators of the last century felt at one point the need to report at the established art in order to better understand the "place" occupied by the generation of new artistic revolutions. This new trend brings back in discussion the classical arts with its perennial values, which can not be overlooked, however radical the desire of young artists is to finally break up with the past. Thus, classical arts such as graphics, painting, or sculpture have once again managed to get out of the shadow cone, which they have been condemned for nearly a century and the works of new figurative artists have again attracted the interest of the public. The technique of modeling appeared at the same time as the first parietal drawings, and some of the first works attesting Homo Sapiens' artistic manifestations are made in this technique. For many centuries the noble art of sculpture has been obsessively focused on human form and its property to express life through three dimensions.

Today, only the connotation of the palpable surface attribute has been preserved. The sculpture defines a class of visible objects which keeps visible roots, inspired by ancient, ancient totemic objects, while looking for innovation in the austere soil of the scientific model and technical inventions. Most differences in art are at some modern trends only at a technical level. In some tendencies, maintaining a humanistic or non-technical ethos has become systematically subsumed. Religion, literary image, fields of art, theater, architecture, painting are the forces that have influenced sculpture in the past which have not escaped by technological demiurg. From both points of view, materialistic and spiritual, modern techniques are responsible for the imminent breake up of sculpture with the past. In this regard, the essayist Friedrich

\footnotetext{
${ }^{280} \mathrm{http}: / /$ www.saatchi-gallery.co.uk/artists/artpages/tracey_emin_my_bed.htm
} 
Junger $^{281}$ admitted fifty years ago that technology is the metaphysical of our century, and time has not diminished Junger's diagnosis.

The continued influence of the technique on sculpture is obvious. Rather, it is a subtle tendency of our culture that all technical novelties be canonized as innovative. Often, the "new" is considered to be part of a "trend-innovation" phenomenon. The desire for "new" comes in part from the unconscious desire of most artists to keep the illusion of individual innovation as an intuitive capacity. This is partly driven by critics who consider their own creative efforts. Each emerging artist assimilates and adapts his artistic approach to the techniques learned during the studies.It seems that Marcel Duchamp had a secret contract to carry out a work which it will be exposed after his death. Etant Donnés is the name of this work. Was the ready-made parent so obsessed by the "death of art" that he would send us this even in his last work, which actually isn't a simply ready - made?
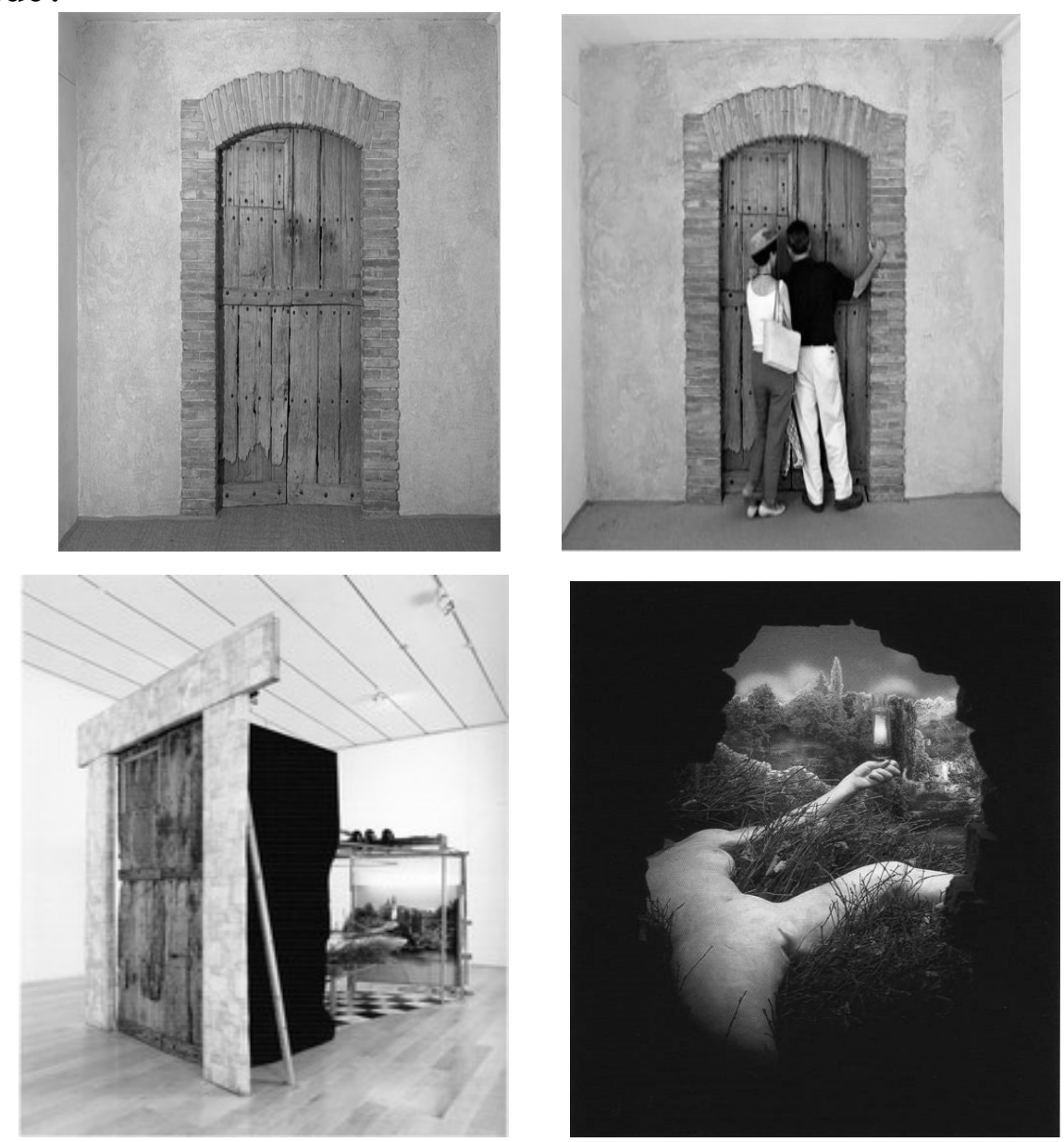

Fig. 4,5,6 și 7. Marcel Duchamp, Etant donnés, instalation, 1946-66, Philadelphia Museum of Art ${ }^{282}$

\footnotetext{
${ }^{281}$ Georg Friedrich Jünger (n.01-09-1898, Hanovra , d.20-07-1977, Überlingen) was an essayist, poet and cultural critic, German

${ }^{282} \mathrm{http}: / /$ www.toutfait.com/issues/issue_3/Articles/Hoy/etantdon_en.html
} 


\section{Conclusions}

The restoration of the path of art evolution to those who want to study sculpture has two meanings. The first is the familiarization with the plastic arts, and the second one is the definition and discovery of one's own style and workmanship. After the future sculptor discovers and practices the techniques that fit personal style, he can go to the search for performance in artistic creation.

\section{References}

1. Argan, Giulio Carlo (1982), Arta modernă, vol. II, Ed. Meridiane, București

2. Arnheim, Rudolf (1979), Arta şi percepţia vizuală, Ed. Meridiane, Bucureşti

3. Bachellard, Gaston (2003), Poetica spaţiului, Ed. Parelela 45, Piteşti

4. Baraschi, Constantin (1962), Tratatul de Sculptură, vol. I, II, Ed. Meridiane, București

5. Comarnescu, Petru, (1972), Confluențe ale artei universale despre Negație și negativism în plastica modernă, Ed. Meridiane, București

6. Focillon, Henri (1977), Viaţa formelor, Ed. Meridiane, Bucureşti

7. Ghiţescu, Gheorghe (1979), Antropologie artistică, Ed. Didactică şi Pedagogică, București

8. Hegel, G.W.F. (1966), Prelegeri de Estetică, vol.1 Editura Academiei Republicii Socialiste România, București

9. Pașca Eugenia Maria, (2013), Arts and inter/cultural education in the European School, Review of Artistic Education. Nr. 6, vol. I, Iaşi

10. Rusu Marilena, (2015), Intercultural Study of Art - Contemporary dimension, Review of Artistic Education, nr. 10, vol. I, Iași

11. Ștefănescu Mircea, (2015), Arta desenului. Studiul portretului și al corpului uman după model, Ed. Artes, Iași

12. Ştefãnescu, Mircea, Ştefănescu, Mirela, (2014), Land Art - The harmony between art, nature, landscape, publicat în Revista Lucrări Științifice a Facultății de Horticultură din cadrul USAMV, vol. 57 , nr.1, Ed. „Ion Ionescu de la Brad", Iași

13. Ștefănescu, Mircea, (2017), The importance of the drawing in the artistic creation process publicat în Review of Artistic Education, no. 13-14/2017, Ed. Artes, Iași

14. Ștefănescu, Mirela, (2017), Arta vizuală ieșeană între tradiție și inovație, Review of artistic education, nr. 13-14/2017, Ed. Artes, Iaşi 